\title{
(2) OPEN ACCESS \\ Ethnography of texts: a literature review of health and female homosexuality in Brazil
}

\author{
Carolina Rau Steuernagel (ㄷ , ${ }^{1}$ Eivind Engebretsen, ${ }^{2}$ Hans Wiggo Kristiansen, ${ }^{3}$ \\ Kåre Moen ${ }^{4}$
}

${ }^{1}$ Department of Community Medicine and Global Health, University of Oslo, Oslo, Norway ${ }^{2}$ Department of Interdisciplinary Health Sciences, University of Oslo, Oslo, Norway ${ }^{3}$ Head Office, Church City Mission, Oslo, Norway ${ }^{4}$ Department of Community Medicine and Global Health, Universtiy of Oslo, Oslo, Norway

\section{Correspondence to}

Carolina Rau Steuernagel, Department of Community Medicine and Global Health, University of Oslo, Oslo 0315, Norway;

c.b.r.steuernagel@medisin. uio.no

Received 26 June 2018 Revised 8 January 2019 Accepted 10 January 2019

Published Online First

13 October 2019

\begin{abstract}
This paper reviews the literature on health and female homosexuality in Brazil and, along the way, outlines an alternative approach to reviewing academic literature. Rather than summarising the contents of previously published papers, we relate to these publications primarily as partakers in the creation of knowledge. Inspired by Actor-Network Theory (ANT), we apply ethnographic methods to understand the papers as study participants endowed with action. We also draw on the notions of inscription and intertextuality to trace the complex relationship between the findings in the articles and the realities outside of them. We claim that 'evidence' is the product of translational processes in which original events, such as experiments, blood tests and interviews, are changed into textual entities. In addition, text production is seen as an absorption of everything else surrounding its creation. When events are turned into articles, the text incorporates the political environment to which original events once belonged. We thus observe a political text inscribed into the written evidence of sexually transmitted infections, and the practice of publishing about scientific vulnerabilities emerges as political action. In contrast with traditional ways of reviewing literature in medical scholarship, this article offers a reminder that although there is a connection between textual evidence and the reality outside publications, these dimensions are not neutrally interchangeable.
\end{abstract}

\section{INTRODUCTION: THE LAST PART WE WROTE}

In this review, we investigate the literature on female homosexuality and health in Brazil. At the same time, we propose a novel way of carrying out reviews.

Our point of departure is that knowledge is not found, it comes into being through processes of translation. Knowledge is the result of twisting, changing, interpreting, merging, counting, inferring, assuming and more. In general terms, translation is a concept that denotes a series of operations that take place and change an original into something else while keeping 'something about it the same'. ${ }^{1}$ Derrida speaks of translation as a 'regulated transformation' ${ }^{2}$ that separates the original from its supplement. In this article, we have applied his conceptualisation of translation to account for the activities of transforming original events, like interviews and blood tests, into knowledge written up in published articles. In order to do so, we take an ethnographic approach to the review of the literature on female homosexuality and health in Brazil.
Almost akin to the human study participants of ethnographic fieldwork, we regard the papers we explored about this topic as our study (or review) participants.

Initially, the idea of an ethnographic approach sprang from our unfamiliarity with the topic we were to explore. None of us had personal experience with it, so to start engaging with it resembled the experience of travelling to a strange and new place to do exploratory fieldwork. Later, we found we could draw a parallel logic between producing culture from ethnographic observations and producing evidence by reading published papers. Rather than considering articles containers of immutable information, they became participants in the knowledge co-creation venture. Once we had made this move, we could observe how articles acted and how they related to one another.

The articles that participated in our review provided us with information about the prevalence of sexually transmitted infections among lesbian women in Brazil, the sexual practices these women engaged in, their 'lack of knowledge' about various issues and their accumulated risk for diseases like cervical cancer and mental disorders. After acknowledging that these findings were outcomes of transformations, we could no longer treat them as neutral facts. We needed different concepts to work with.

First, in acknowledging that published articles are writings, we turned to the notion of inscription as developed by Derrida and further elaborated in the work of Latour and Woolgar. ${ }^{3}$ Inscription refers to the activity of making something transitory into something durable and portable. ${ }^{4}$ With the aid of this concept, we were able to analyse the processes of translating events (like interviews and blood tests) into the written information we had access to in the papers we read.

Second, in acknowledging that writings do not emerge in a vacuum, we used Kristeva's ${ }^{5}$ concept of intertextuality to understand texts (our review participants) as an absorption of everything surrounding their creation. According to Kristeva, any text is 'a mosaic of quotations; any text is the absorption and transformation of another'. ${ }^{6}$ For instance, alongside with interviews, also the political, historical and ideological environment in that they once belonged had been turned into written material. We came to recognise the articles-the texts-we were exploring as a play on other texts, meaning that each text endlessly refers to further elements within the production process. ${ }^{7}$ 
In sum, this article presents a review, and-alongside it - a discussion of the ways in which we created that review. Through the latter, we hope to contribute to ongoing discussion in medicine and health research, where many authors have called for alternative ways of looking into evidence. ${ }^{8}$ Medicine tends to highlight reviews as tools to 'synthesise a large body of evidence', and reviews that do so have become the gold standard for guiding clinical practice in evidence-based medicine (EBM). However, several authors have argued that EBM is currently facing a serious crisis due to the ways in which evidence is understood, used and produced. ${ }^{10}$ Yet, instead of rejecting EBM as a failed model, some critics have suggested that the EBM movement could be advanced through more use of narratives, experiences, theories and qualitative inquiry informing the production of evidence. ${ }^{11}$ Engebretsen et al emphasises the 'creative potential' of the translational process in producing evidence. ${ }^{12}$ In addition, a recent publication by Kristeva et al highlights the relevance of approaches questioning the conventional distinction between the 'objectivity of science' and the 'subjectivity of culture', calling for a rethinking of the concept of evidence $^{13}$. In this article, we aim to contribute to these discussions by introducing ethnography of texts as an approach for reviewing literature. By allowing subjectivity as an integral part in the process of producing knowledge, this review offers fresh insights concerning ways of understanding what evidence is, and delineates novel ways of using and producing it.

In order to make the manufacturing processes of this article more visible for the reader, we have divided the text to reflect the chronological order of our various drafts of it. But first, we need to lay a theoretical foundation for our ethnographic approach.

\section{ETHNOGRAPHY: WHERE THE IDEA COMES FROM AND WHEN WE STARTED TO RECOGNIZE THE WORK OF PRODUCTION}

'An ethnographic account is conventionally the description of a particular society and culture known to be based at some point on the experiences and observations of a fieldworker who was there. ${ }^{14}$ This is how Strathern starts her reflections about anthropological production ${ }^{15}$ and the many dissonant voices that debate the representation of 'society' and 'culture' through ethnography. The discussion turns on the understanding that there is no ethnography without the ethnographer. As logical as this may seem, the implications of this insight became the object of debate some decades ago. ${ }^{16}$ Of course, the presence of the ethnographer had been acknowledged earlier, but the effect of this presence on the very idea of 'culture' and 'society' became the main discussion. The ethnographer is a 'medium that already has a form of its own', ${ }^{17}$ and the idea of ethnographic account as mere description or transparent representation of a given society or culture came under attack. ${ }^{18}$ Rather than a neutral vessel through which culture or society can be transported, the work of the ethnographer is the very condition of existence of society and culture.

Let us explain. While in the field, the ethnographer interacts with study participants, observes the relationships between them, and learns local meanings and rules. (S)he accumulates a diversity of experiences in situ. ${ }^{19}$ However, the interactions between researcher and study participants are not replicated one-to-one in the ethnographic report. Rather, as Strathern points out, it is the generalised information about these experiences-what is common to many of them-that can be aggregated as the 'culture' of a group of people. ${ }^{20}$ In order to produce a coherent text, the ethnographer connects the events in which (s)he participated into an organizing entity. This entity goes by the name 'society' or 'culture' ${ }^{21}$. At the conclusion of the study, the ethnographer writes a report, which is a holistic, unifying assumption about the integration of meaning regarding his/ her experiences in the field. ${ }^{22}$ This reflection has led authors to conclude that not only is there no ethnography without the ethnographer but also that there is no culture or society without the ethnographer's unifying and interpretative presence. The work of the ethnographer is already contained within the origin of a given culture or society, as a condition of its existence.

We have borrowed past anthropological discussions about the relationship between text - the ethnographic account-and the notion of society or culture in order to help us reflect on the relationship between our texts-the articles we have studied-and the notion of 'knowledge' or even 'evidence' in health research. To fuse experiences from the field into a description of an overarching entity resembles the underlying aim in traditional ways of reviewing scientific papers. Commonly, reviews provide descriptions of scientific knowledge published somewhere else-what is already known about a certain theme or phenomenon-in order to provide a foundation for further research or practice. ${ }^{23}$ In ethnographic research, the idea of culture or society is no longer seen as a mere description of a reality out there. Rather, ethnographic work is the condition for the existence of culture or society. Once this ethnographic rationale is applied to explore scientific publications and these publications acquire the status of study participants, this exploration can no longer claim to be a mere representation of the already established knowledge about a topic, such as health and female homosexuality in Brazil, or to present a unified whole about it. The debate about representation has urged alternative ways of carrying out research, which understand ethnography as means to interfere with the world, 'not a way of opening a window on the world'. ${ }^{24}$

It is important to emphasise that anthropology is not, of course, claiming that culture and society do not exist out there. Neither do we argue that our object of study-the knowledge about same-sex attracted women and health in Brazil 'out there'-does not exist. The debate we engage with here revolves around how research mediates between the world and various accounts of it; how research interferes with participants; how the 'culture' in the ethnographic account is dependent on the work carried out by the ethnographer. Rather than understanding ethnography as a tool to access reality, we use it as a medium to interfere with reality.

We draw on ethnography here to state the obvious: the information about health and female homosexuality we provide in this review is the outcome of manufacturing work. Each article was selected, read, re-read, translated from Portuguese to English when necessary, reflected on and written about. There is no literature review without the work of reviewing.

\section{ENLISTING PARTICIPANTS AND DRAFT ONE}

In Table 1, we have listed 14 papers that took active part in the production of this review article. Along the way, we encountered many other texts (such as reports, doctoral and master theses, unpublished material, news reports, and governmental publications) that also contributed to the production of our text (and to the writings listed in Table 1). Just as the ethnographer does not replicate all field conversations in an ethnography, nor accounts for the relationship with each individual informant, ${ }^{25}$ we also avoided trying to do so. Thus, the list in Table 1 names the participants we came to know the best, not all the informants that contributed to our perspectives. 


\begin{tabular}{|c|c|c|c|}
\hline $\begin{array}{l}\text { Name of } \\
\text { author(s), } \\
\text { publication } \\
\text { year }\end{array}$ & Title & $\begin{array}{l}\text { Journal, language, } \\
\text { pages }\end{array}$ & Approach \\
\hline $\begin{array}{l}\text { Pinto et al } \\
(2005)^{69}\end{array}$ & $\begin{array}{l}\text { Sexually transmitted } \\
\text { disease/HIV risk behaviour } \\
\text { among women who have } \\
\text { sex with women }\end{array}$ & $\begin{array}{l}\text { AIDS, English, } 5 \\
\text { pages }\end{array}$ & $\begin{array}{l}\text { Cross-sectional } \\
\text { epidemiological study }\end{array}$ \\
\hline $\begin{array}{l}\text { Barbosa and } \\
\text { Koyama }(2006)^{70}\end{array}$ & $\begin{array}{l}\text { Women who have sex } \\
\text { with women: estimates } \\
\text { for Brazil }\end{array}$ & $\begin{array}{l}\text { Cadernos de Saúde } \\
\text { Pública, Portuguese, } \\
3 \text { pages }\end{array}$ & National survey \\
\hline $\begin{array}{l}\text { Almeida and } \\
\text { Heilborn } \\
(2008)^{71}\end{array}$ & $\begin{array}{l}\text { Não somos mulheres } \\
\text { gays: identidade lésbica } \\
\text { na visão de ativistas } \\
\text { brasileiras (We are not } \\
\text { gay women: lesbian } \\
\text { identity as viewed by } \\
\text { Brazilian activists) }\end{array}$ & $\begin{array}{l}\text { Gênero, Portuguese, } \\
24 \text { pages }\end{array}$ & $\begin{array}{l}\text { Interviews, } \\
\text { participant } \\
\text { observation }\end{array}$ \\
\hline Facchini $(2008)^{72}$ & $\begin{array}{l}\text { Mulheres, (homo) } \\
\text { sexualidades e diferenças: } \\
\text { uma reflexão sobre } \\
\text { políticas públicas } \\
\text { segmentadas (Women, } \\
\text { (homo)sexualities and } \\
\text { differences: a reflection } \\
\text { about targeted public } \\
\text { policies) }\end{array}$ & $\begin{array}{l}\text { Reunião Brasileira } \\
\text { de Antropologia, } \\
\text { Portuguese, } 22 \text { pages }\end{array}$ & Conference paper \\
\hline $\begin{array}{l}\text { Almeida } \\
(2009)^{73}\end{array}$ & $\begin{array}{l}\text { Arguments of the } \\
\text { possibility of STD } \\
\text { infection and Aids among } \\
\text { women that define } \\
\text { themselves as lesbians }\end{array}$ & $\begin{array}{l}\text { Physis: Revista de } \\
\text { Saúde Coletiva, } \\
\text { Portuguese, } 30 \text { pages }\end{array}$ & $\begin{array}{l}\text { Interviews, } \\
\text { participant } \\
\text { observation }\end{array}$ \\
\hline $\begin{array}{l}\text { Barbosa and } \\
\text { Facchini }(2009)^{74}\end{array}$ & $\begin{array}{l}\text { Access to sexual } \\
\text { healthcare for women } \\
\text { who have sex with } \\
\text { women in São Paulo, } \\
\text { Brazil }\end{array}$ & $\begin{array}{l}\text { Cadernos de Saúde } \\
\text { Pública, Portuguese, } \\
9 \text { pages }\end{array}$ & $\begin{array}{l}\text { Interviews, } \\
\text { participant } \\
\text { observation }\end{array}$ \\
\hline $\begin{array}{l}\text { Reis et al } \\
(2010)^{75}\end{array}$ & $\begin{array}{l}\text { Genital and oral human } \\
\text { papillomavirus infection } \\
\text { in a patient from the } \\
\text { group of women who } \\
\text { have sex with women }\end{array}$ & $\begin{array}{l}\text { Clinics, English, } 3 \\
\text { pages }\end{array}$ & Case report \\
\hline $\begin{array}{l}\text { Mora and } \\
\text { Monteiro } \\
(2010)^{76}\end{array}$ & $\begin{array}{l}\text { Vulnerability to STIS/ } \\
\text { HIV: sociability and the } \\
\text { life trajectories of young } \\
\text { women who have sex } \\
\text { with women in Rio de } \\
\text { Janeiro }\end{array}$ & $\begin{array}{l}\text { Culture, Health and } \\
\text { Sexuality, English, } 9 \\
\text { pages }\end{array}$ & $\begin{array}{l}\text { Interviews, } \\
\text { participant } \\
\text { observation }\end{array}$ \\
\hline $\begin{array}{l}\text { Rodrigues and } \\
\text { Schor }(2010)^{77}\end{array}$ & $\begin{array}{l}\text { Saúde sexual e } \\
\text { reprodutiva de mulheres } \\
\text { lesbicas e bissexuais }\end{array}$ & $\begin{array}{l}\text { Fazendo Gênero } \\
\text { 9: Diásporas, } \\
\text { Diversidades, } \\
\text { Deslocamentos, } \\
\text { Portuguese, } 11 \text { pages }\end{array}$ & Conference paper \\
\hline $\begin{array}{l}\text { Bertolin et al } \\
(2010)^{78}\end{array}$ & $\begin{array}{l}\text { Knowledge of women } \\
\text { who have sex with } \\
\text { women about human } \\
\text { papillomavirus }\end{array}$ & $\begin{array}{l}\text { Cogitare } \\
\text { Enfermagem, } \\
\text { Portuguese, } 5 \text { pages }\end{array}$ & Questionnaire survey \\
\hline $\begin{array}{l}\text { Valadão and } \\
\text { Gomes }(2011)^{79}\end{array}$ & $\begin{array}{l}\text { Female homosexuality in } \\
\text { health: from invisibility to } \\
\text { violence }\end{array}$ & $\begin{array}{l}\text { Physis: Revista de } \\
\text { Saúde Coletiva, } \\
\text { Portuguese, } 16 \text { pages }\end{array}$ & $\begin{array}{l}\text { Review of articles } \\
\text { and documents }\end{array}$ \\
\hline $\begin{array}{l}\text { Mora and } \\
\text { Monteiro } \\
(2013)^{80}\end{array}$ & $\begin{array}{l}\text { Female homoeroticism, } \\
\text { young people and } \\
\text { vulnerability to STI/Aids }\end{array}$ & $\begin{array}{l}\text { Estudos Feministas, } \\
\text { Portuguese, } 21 \text { pages }\end{array}$ & $\begin{array}{l}\text { Interviews, } \\
\text { participant } \\
\text { observation }\end{array}$ \\
\hline $\begin{array}{l}\text { Carvalho et al } \\
(2013)^{81}\end{array}$ & $\begin{array}{l}\text { Prevention of sexually } \\
\text { transmitted diseases by } \\
\text { homosexual and bisexual } \\
\text { women }\end{array}$ & $\begin{array}{l}\text { Online Brazilian } \\
\text { Journal of Nursing, } \\
\text { English, } 10 \text { pages }\end{array}$ & $\begin{array}{l}\text { Semi-structured } \\
\text { interviews }\end{array}$ \\
\hline $\begin{array}{l}\text { Carvalho et al } \\
(2013)^{82}\end{array}$ & $\begin{array}{l}\text { The device 'health of } \\
\text { lesbian women': (in) } \\
\text { visibility and rights }\end{array}$ & $\begin{array}{l}\text { Psicologia Política, } \\
\text { Portuguese, } 16 \text { pages }\end{array}$ & Critical review \\
\hline
\end{tabular}

We came across some of the review participants through database searches for articles related to our main topic of interest. As we expected the number of articles to be small, we aimed to gather all publications related to this topic. We used terms such as 'lesbian women', 'lesbians', 'women who have sex with women' (or the acronym WSW), 'same-sex attracted women' and 'female homosexuality'. We searched for terms both in English and Portuguese. All participating articles focused on health-related issues in Brazil. In a second moment, we used a purposive snowball sampling strategy to include additional review participants among papers quoted or mentioned in the initial sample. Our aim was to select articles that would contribute to a wide variety of perspectives and articles where significant aspects of the phenomena under study were most pronounced. $^{26}$

In Table 1, we have listed the review participants by publication date (their birth date, as it were) and included some background information about them that we consider contextually relevant. 'Name of author(s)' and 'publication year' are provided so that we can identify the papers in our text. 'Title' reflects the authors' take on the themes discussed in the articles. When an English title was not available, we decided to keep the original Portuguese wording in the table and provided the reader with our English translation of it. 'Journal name' and 'language' give an idea of the accessibility and potential scope of influence of each paper, and the number of pages offers an impression of the length of each paper. 'Approach' allude to the ways or settings in which knowledge was produced.

All articles were printed on paper and read several times. As one of the authors is Brazilian and reads Portuguese, it was not necessary to translate all papers in order to analyse them. Some parts of the texts were highlighted with text marking pens, and we hand-wrote notes on some of the printouts. Information contained in the texts was written down in order to generate our first set of 'field notes'.

We thereafter developed the first draft of this article (Draft One), which contained a description of the papers and identified themes that seemed to be common among them. Special attention was paid to cross-references between the articles. An early observation was that all the articles framed health issues mainly in relation to sexual health. We also noticed that the terminology used to group the women together differed between articles. Among terms in use were 'lesbians', 'lesbian women', 'women who have sex with women', 'WSW' and several other terms. We decided to always borrow the study participant's own terms, when referring to their statements.

\section{DRAFT TWO: ARTICLES AS PARTICIPANTS}

At this point, the task of relating to scientific and scholarly papers as study participants demanded a reflection about theoretical foundations for this move. A second draft of this article was experimented with as we engaged with this task. It aimed to focus on the part articles were playing in the creation of the review.

Theoretical insight from Actor-Network Theory (ANT) ${ }^{27}$ motivated an emphasis on the papers' ways of acting. ANT suggests that both human and non-human actors participate in the production of events and phenomena studied in social world. ${ }^{28}$ However, rather than being a pure and unproblematic source of action, ANT understands an actor as the target of a variety of actions directed towards it. ${ }^{29}$ 'An actor is what is made to act', not the origin of an action. ${ }^{30}$ This perspective was helpful because it promoted a shift in our way of observing the articles and the relationships between them. We started to consider anything capable of acting: the articles themselves, the authors and the findings; they were all doing something. 
We then turned our attention to what was making them act. We refer to this as the review participants 'surroundings' or “environment' - even as their 'context'. However, with regard to the latter of these terms, it is important to emphasise something. The word 'context' is often associated with the words 'cultural', 'economic' or 'sociopolitical', as a general dimension that explains actions. Our notion of 'context' was rather the opposite. It was very narrow and uncertain. We took the actor as a starting point to observe and describe 'context' - the associations that were enabling the review participants' action. The 'context' was the direct relationship that made their actions possible: the conditions necessary for action to occur. We did not know what these 'contexts' might be at the onset of the study, but these gradually became a main focus of our attention. We recognised that the act of publishing an article was influenced by surrounding conditions, as for instance claims made in other papers, which in turn deserved investigation.

The paper authored by Reis et $a l^{31}$ was crucial in this respect. It is a case report. In health research, case reports have the function of exploring singular events, investigating events in depth, or raising the importance of something. ${ }^{32}$ Reis' report raises the issue that there is a chance for sexual transmission of disease between women:

Both women denied past history of STDs [sexually transmitted diseases] and heterosexual intercourse; but they did declare previous relationships with digital-vaginal and digital-anal practices, as well as vulvar and oral-to-oral contact. Biopsy results for lesions of the lips and vulvas revealed condyloma acuminata. ${ }^{33}$

Condylomata acuminata is one of the conditions associated with the human papillomavirus (HPV), a virus connected to several sexually transmitted infections, including genital and oral warts. ${ }^{34}$ In addition, HPV is described as having oncogenic potential. $^{35}$ The paper by Reis et al contains four photographs: one showing multiple and confluent warts on a vulva, one depicting gum warts and two presenting microscopic images of these lesions. ${ }^{36}$ The patient in this case referred to herself as lesbian. In the text, she is said to represent the WSW category (women who have sex with women). It is clearly important that she declared that she had been in a stable relationship with a woman for the 16 months preceding the study and that both she and her partner claimed to never have had sex with men. The article states that the woman was a 'WSW with intact hymen', ${ }^{37}$ thus emphasising that professional observation was consistent with the woman's assertion that she had never had heterosexual intercourse. This emphasis is made because the article draws attention to a significant finding: the woman had contracted a sexually transmitted disease although she had only had sex with other women. By emphasising this association, this case report becomes evidence that STDs may be sexually transmitted between women.

The perspective that an actor is made to act led us to explore the surrounding conditions that allowed for the publication of Reis et al. We noticed that their case report would only be worth writing and publishing in surroundings where sexual transmission of diseases between women was considered an extraordinary event. This perspective turned our observation to these surroundings: the other papers we were reading. They did indeed state that sexual transmission between women was something unknown. We inferred that the 'context' necessary for the publication of Reis et al was made up of this very claim.

Bertolin $e t a l^{38}$ is an example of this 'context'. This study evaluates the knowledge women who have sex with other women have about HPV and states that women do not know that they can acquire HPV by having sex with other women. Here we started to realise that the principle of observing the condition of existence of statements and claims in our papers, and the conditions allowing their publication, as we had done with Reis et al, was useful. It provided us with a way of connecting the articles to each other without having to summarise their information.

We also observed for the first time the relationship between claims in the papers and the general knowledge about their 'findings'. In addition to the connections between the articles we could now see, this rather unusual way of working had provided us with a way to move forward.

\section{Sex with women, sex with men}

In recognising the participating articles as actors made to act, we could observe the ways in which they influenced each other. Instead of asking what a given text was saying, we started to ask why it had been published in the first place. We asked what were the surrounding conditions that allowed the paper's claims to have meaning.

A first and obvious way of seeking understanding of what motivates the publication of an article, or the claims it makes, is to pay attention to the reasons stated by its authors. Articles usually base their arguments in other articles. This is habitually done by presenting a quote, inserting a name (or a number) after it, and making a list of these names under the heading 'references'. ${ }^{39}$ Like we did just now. However, we also noticed that many arguments justifying the publication of articles had no references. In scientific articles, the practice of referencing seems to be associated with the confidence in the claim made. ${ }^{40}$ When an argument is contested, or when there is doubt around it, the practice of referencing seems to enhance the factuality of the claim. Conversely, in the case a paper makes a claim that requires no discussion, there is less of a need to reference it. In the following (translated) quote for instance, Barbosa and Koyama did not provide any citation.

The emergence of the epidemics of AIDS exposes a growing preoccupation with sexuality, particularly issues related to male homosexuality. Yet, female homosexuality and its relationship with health was kept marginal to this process. $^{41}$

In attending to the associations between claim making and the practice of referencing, we also observed that absencesthat is, a lack of scientific knowledge or publications about a topic-were often not documented. Often, when an absence was claimed, articles had no way of referencing it. Pinto et al provides an example:

The frequencies of different sexually transmitted diseases (STD) and risk factors related to gynecological cancer among women who have sex with women (WSW) in Brazil is little known. ${ }^{42}$

It is interesting to note that the motivation for the study carried out by Pinto et al is a claim in its own. The references presented throughout the paper relate to studies about the frequency of STDs abroad. Pinto et al claimed that the topic they were investigating was 'little known' in Brazil. This claim enabled the study to justify itself. The absence of previous studies created a medium-a context - that permitted tests to be carried out among Brazilian same-sex attracted women in order to detect and quantify the presence of sexually transmitted infections among them. In the Pinto paper, these tests had been translated into frequencies of trichomoniasis, bacterial vaginosis, fungal infections, chlamydia, hepatitis, abnormal Pap smears, HPV infections and HIV. The authors had also carried out a questionnaire survey in 
order 'to identify data relating to possible risk factors for STD/ HIV'. ${ }^{43}$ Risk factors were translated into: having sex with men in addition to having sex with women, not using condoms, sharing sex toys and having sexual intercourse while menstruating. ${ }^{44}$ All these activities and practices were said to be related to the possibility of being infected. Pinto et al claimed that something that had been happening in other countries, happened in Brazil as well. ${ }^{45}$ Women who had sex with women may have sex with men too and could thus get infected with STDs.

When comparing Pinto et al with Reis et al, we observed that there was a time lapse between the two publications. Also, while Pinto examined the occurrence of sex with men among the same-sex practicing women they studied, and linked this to a risk for STDs, Reis suggested that even sex between women could bring about transmission of such diseases. It became clear for us that a connecting element existed between the two papers: for both review participants, the possibility of infection was framing the work of research and publication. We noted that this argument was still controversial, because whenever the possibility of infection was mentioned, there was a need to provide references.

Yet, we arrived at an even more captivating inference in draft two. There was a strong association between the new 'evidence of infection', and the assumption that a lack of knowledge about this possibility exists. We observed that only Bertolin et al engages in evaluating knowledge about sexually transmitted infections. In the other articles, the possibility of infection as new established fact becomes the foundation to claim that very little is known about it. In the following, we have listed some examples of how this occurred in the papers:

- In Reis et al: 'This case report clearly illustrates the need for specific orientation about HPV infection targeted at women who have sex with women (WSW)'. ${ }^{46}$

- In Pinto et al: 'It is evident that there is a need for healthcare professionals to be correctly informed and sensitive toward the healthcare of WSW'. ${ }^{47}$

- In Barbosa and Facchini (translated): 'The lack of knowledge in Brazil about the health needs of this population is evident'. $^{48}$

- In Mora and Monteiro: 'The notion of STI and HIV risk is not well developed among women who have sex with women'. ${ }^{49}$
From this understanding, we identified a thin grid holding our review participants together: the work of publishing was, in one way or another, connected to the possibility of infection among same-sex attracted women plus a shortage of information about that very possibility. Figure 1 illustrates these connections. We have placed inside circle A the different activities the papers claim make infection possible. For our review participants, these activities worked as means through which the 'possibility of infection' comes to exist. Circle B contains the different persons and settings where the 'need for information' about these possibilities was allocated in the papers. We noted that we could associate one or more items in A with one or more items in B. Through this exercise, we were able to identify a basic structure in the process of making claims in the articles under review: the assertion that 'need for information' existed (for instance among women themselves or among healthcare providers) was dependent on the existence of the 'possibility of infection'. In other words: the claims in circle B were dependent on the evident existence of items in circle A.

We further noticed that once a relationship between A and B had been established, the papers were free to focus their attention on the circumstances surrounding this relationship. In the publication by Barbosa and Facchini, for instance, claims are generated on the basis of an association between A and B. The paper argues that women who have sex with women have 'difficulties in accessing healthcare, ${ }^{50}$ specified as gynaecological care. By looking at the condition of existence of this claim, we could observe the presence of the underlying association between A and B as an established fact. Consider the following example (translated) from the paper:

Among those [interviewed women] with none, or few and irregular consultations, it was very common to refer to a lack of 'necessity' [of going to the doctor]. The argument included: a "lack of need" due to "not being at risk" and "not having symptoms". 51

The logic in this quote is: because the interviewed women asserted that they did not need healthcare (they stated that they were not at risk and/or that they did not have symptoms), it affected their search for healthcare. The 'lack of necessity' is an argument producing 'none or few and irregular consultations'. When we analysed the conditions of existence for the claims in

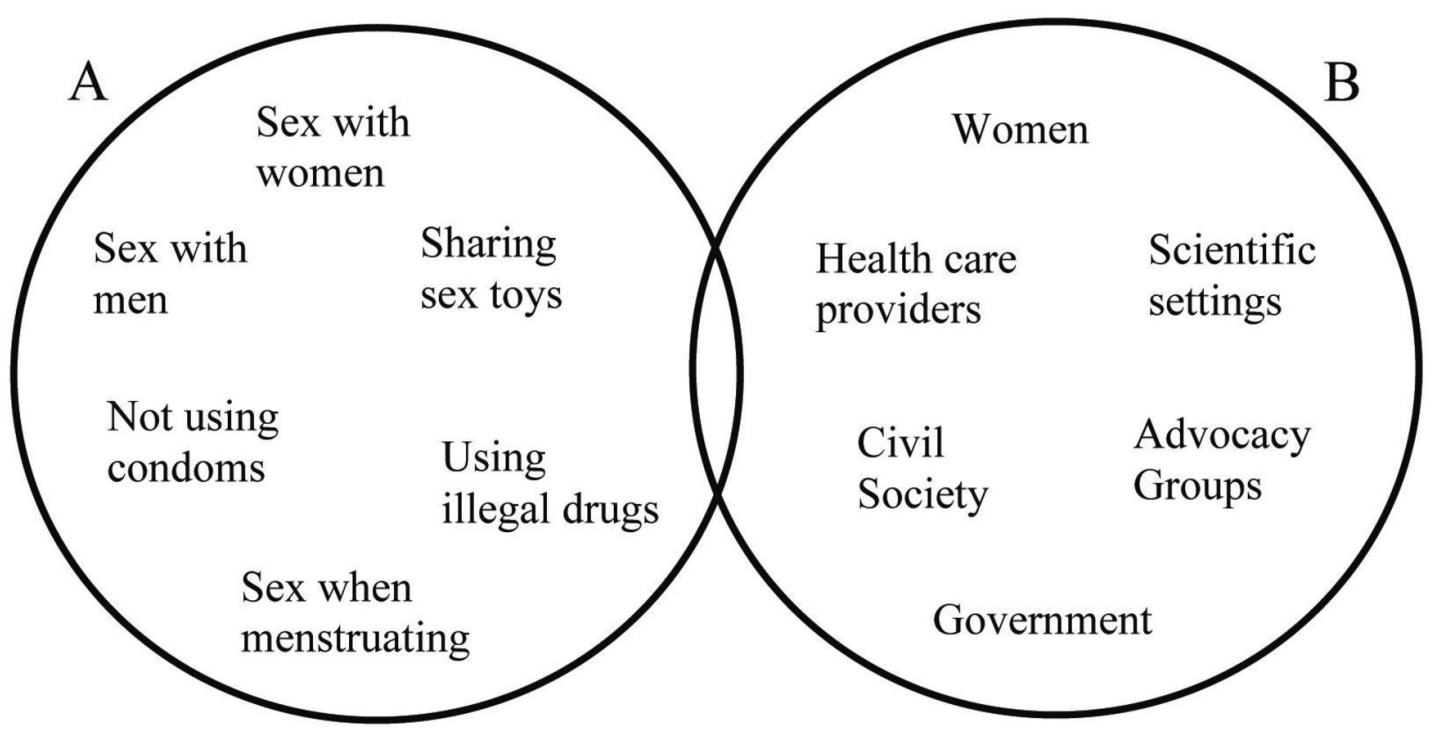

Figure 1 A basic structure for claim making. 
the paper, we observed the existence of the association between $\mathrm{A}$ and $\mathrm{B}$ as a foundation. The article's claim is produced based on the established understanding that women are at risk but do not know about this risk. In this scenario, where the association between $\mathrm{A}$ and $\mathrm{B}$ already exists, not searching for healthcare becomes a problem. Since the association between A and B is already in place, it allows the article to question the women's argument (lack of necessity) and recast it (1) as women's misconceptions and (2) as causing women not to access healthcare.

Until this point, we were pleased with our ethnographic approach and with the freedom we had gained from the principle of treating articles as study participants. However, we slowly came to recognise that in our attempt to approach articles as participants and looking at their surroundings, we had gradually introduced a bias, a sort of favouritism, in our reflections: the health of same-sex attracted women in Brazil, our main study object, was slowly evaporating from our text. Taking Barbosa and Facchini ${ }^{52}$ again as an example. As we highlighted the conditions of existence of this paper's claims, it seemed that we had left out the claims themselves. In other words, was there really a possibility of infection? Was it a problem if lesbian women did not search for healthcare? Were we ignoring the papers' content by only looking into their 'context'? Our overarching question now became: What is the relationship between the claims in the papers and the reality outside of them? This question led us to start anew.

\section{DRAFT THREE}

While we had initially meant to write a single review article, we now came to consider splitting the manuscript so that it would become two different but related articles. The first would provide a theoretical foundation for the way we were investigating written texts, and the second would contain a practical application of the theory explored in the first. The possibility of writing two articles provided opportunity for an investigation of theories about translation and knowledge production and about philosophy of language. We used these theories to expand our understanding of articles as actors by exploring not only the conditions of existence of the health of Brazilian same-sex attracted women in the literature, but by investigating our study object itself and tracing the relationship between the articles and the realities outside of them.

While we first explored philosophy as a tool to understand properties of texts, we later came to recognise its practical application. One of the articles we were reading contained a feature that was particularly helpful in this respect. Almeida is an article based on an ethnographic study among lesbian activists. ${ }^{53}$ Throughout the article, the author applies the term 'lesbian body' (in Portuguese: corpo lésbico), which is said to encompass how the participants in the study presented their bodies and their health claims in a setting of political activism. However, the participants in the study had never used this term themselves. It was an invented term, manufactured by the author in the writing process:

The lesbian body was a fiction (...) sanctioned by the need to understand how a certain group (strategic in publicly establishing a lesbian identity) thinks itself. (...) I have tried to show how - in a certain political and cultural scenario-a group of individuals who are leading a social movement in expansion represented their bodies and their health needs. (translated) ${ }^{54}$

From philosophy of language, we have applied to Almeida's 'lesbian body' two main concepts: (1) Jacques Derrida's notion of inscription ${ }^{55}$ and (2) the notion of intertextuality, a term first coined by Kristeva. ${ }^{56}$ While the reflections about inscription follow below because this concept played a substantial role in draft three, intertextuality only emerged in our last draft, and is thus described later in this paper.

\section{Inscription}

The notion of inscription pertains to the process of translating events into objects.

In Almeida's article, the experiences participants shared with the researcher, the events that took place during fieldwork and the relationships between researcher and researched are not replicated in the text, but translated into a written entity. They are inscribed into-embedded and imprinted in - a textual form: the expression 'lesbian body'.

The process of inscription is more than just describing events that have occurred, transcribing interviews that have been carried out or writing down meanings that have been understood. It is the process of making something transitory into something durable and portable. ${ }^{57}$ Because the manufacturing of the 'lesbian body' is so clear in Almeida's text, it highlights the inscription process, the transformation of events into a written entity.

Derrida's notion of inscription, however, suggests that the processes entailed in translating events into this kind of durable object 'forbid at any moment, or in any sense, that a simple element be present in and of itself' ${ }^{58}$ In other words, the textual entity, the 'lesbian body', can never correspond to each event that participated in its creation. It can provide us with traces of what has happened along the way, but it cannot replicate every occurrence one-to-one. ${ }^{59}$ The manufactured 'lesbian body' is not capable of bringing us face to face with everything that happened in the past. The interviewed women continued to exist after the interviews had taken place, as did the researcher and the device used to record the conversations. But the exact configuration of what happened is absent. We cannot recollect the past. Everything that happened is now translated into a written form, the 'lesbian body'. The lesbian body was never a woman, nor a group of women; it came into being when the text about what happened in the past was created.

The implications of the notion of inscription applied to the 'lesbian body' are both simple and revealing. They helped us to understand that although the 'lesbian body' contained traces of events that had happened, to comprehend it as a direct link with an outside reality, that is, past events, would be mistaken. Returning to the question we asked ourselves above, the reason for this philosophical inquiry-is there really a possibility of infection-we now had the means to answer it with confidence. The articles we were reading contained traces of it. But to recognise these traces as pure reality, and to forget the processes through which events were crafted into information in the articles, was not tenable.

We concluded that the notion of inscription enabled two main understandings that we could take forward: (1) the 'lesbian body' comes into being by means of the text, it is dependent on the text, and (2) the 'lesbian body' contains a multiplicity of traces of events, women, researcher and interviews. The effect of these two main points, however-which has implications for the way scientific reviews (in general) are often carried out-we only realised in draft four when we arrived at the notion of intertextuality. Thus, we leave this argument open for now, reengaging with it at the end of the article. 


\section{Vulnerability produced}

As the 'lesbian body' was an evident effect of the inscription process, we decided to follow it, and to observe the associations out of which it was made. We could observe that the 'lesbian body' was able to assume different features, depending on the scenario in which it was participating. For instance, in relation to the HIV epidemic in Brazil, the 'lesbian body' assumed the feature of invisibility:

Until the 1990's in Brazil, the possibility of infection of the "lesbian body" was not taken into consideration in the public arena of Aids (in health policies and in the repertoire of the homosexual movement itself). This invisibility was also closely related to the ways in which epidemiology understood the transmission chain of the virus: ruled by the idea that sharing corporeal fluids was necessary-the absence of penetration and contact with corporeal fluids made the "lesbian body" averse to HIV infection, inversely proportional to the "gay body" at the centre of the epidemic. (translated) ${ }^{60}$

Because the 'lesbian body' is said to be unfit for penetration by corporeal fluids, which in turn are said to contain the virus, it had no opportunity to be infected by HIV. When the HIV epidemic is the stage, the 'lesbian body' is invisible. The lack of the distinguishing male features of its counterpart-the 'gay body'-is the main feature of the 'lesbian body'. ${ }^{61}$ In contrast, when placed within health policies pertaining to women, the 'lesbian body' acquires female features:

It is about the perception that the "lesbian body" is, before anything else, a feminine body (gendered) and thus, similar to other feminine bodies that historically, in the light of gynecology and hygiene, were seen as intrinsically pathological. In this way, lesbians were recognized as vulnerable to STD and Aids because of their gender specificities—anatomic and/or cultural— that inevitably attach them to a feminine gender. Thus, gonorrhea in women is harder to detect than in men, because in women it is internal, while in men it is easier to see. (translated) ${ }^{62}$

When the context is healthcare for women, the 'lesbian body' is said to have feminine characteristics, endowed with the same features as those that pertain to all women: the same possibility of being infected with STDs and AIDS. Considered as that of a woman, the 'lesbian body' is, in this context, anatomically and culturally female, internal, where diseases can hide.

In accounting for the conditions of existence of the 'lesbian body' in both scenarios, we could understand this entity as part of the association between the 'possibility of infection' (A) with the allocated 'need for information' (B) produced in draft two. Once the association between $\mathrm{A}$ and $\mathrm{B}$ had been established, the 'lesbian body' could be made to fit with the scenario. And it seems to be made to fit to highlight vulnerabilities. For instance, in a scenario where HIV can infect the 'lesbian body' (ie, the possibility of infection is established by any of the practices inside circle A), but this body is not visible (because there is a shortage of information allocated in some or any of the placeholders in circle B), the 'lesbian body' is vulnerable. In addition, in a scenario where lesbians can be infected by STDs just as all other women can (A), but healthcare providers do not know of or disregard this possibility (B), the 'lesbian body' is vulnerable. In both settings, therefore, the 'lesbian body' is made to fit-as either invisible or female-with that which is vulnerable.

We thus concluded that in relation to our ethnographic approach to scholarly articles conceived of as actors made to act, we now had a better grasp of the practices at work through which the health of same-sex attracted women comes into being. First, we noticed the work of establishing the association between the 'possibility of infection' (A) with an allocated 'need for information' (B), as described in draft two. Second, in applying the notion of inscription, it was possible to observe that the lesbian body as vulnerable is crafted of this relationship between A and B. Through the text, by means of the text, vulnerability is the inscription of the association between $\mathrm{A}$ and $\mathrm{B}$.

At this point, we had come to realise that it was possible to apply the philosophical theories we had explored at length in draft three to understand the content of the papers in a very concrete way. We were therefore motivated to abandon the idea of writing two articles, as we had planned when we started working on draft three, and to proceed with the compilation of our reflections so far into a single and final draft.

\section{DRAFT FOUR: WHEN WE ARRIVED AT A CLOSURE}

The notion of inscription has left us with an open end to close. What are the effects of understanding that the 'lesbian body' contains traces of events, experiments, viruses, interviews and so on? Or, in other words, what are the consequences of recognising that the findings in our participating articles contain traces of the events giving origin to them? A critical point in Derrida's theory is that it opposes the idea that the written entity (which in our case is the 'lesbian body') is a storage medium, or a direct link with an outside reality. ${ }^{63}$ In other words, that the written entity is a neutral representation of an original object. If we come to terms with this philosophical argument, there is no original object to begin with. If we again take the lesbian body as example, there is no original 'lesbian body', only interviews between women and researcher left in the past, translated into written material.

To accept this philosophical claim is by no means to claim that interviews did not take place, or that lesbian women are not really vulnerable. (Or, if we bring up again the reflections about representation in ethnography, that the culture out there does not really exist.) It is a way to remind us that what we have at hand when reading a paper is the outcome of a series of transformations. In effect, the use of such philosophical intakes provided us with a system to take up scientific articles and recast them objectively: as mediators between that which has happened and that which continues to happen. We have used philosophical concepts to reassert the obvious: That papers are papers. The most appealing outcome in this approach, however, is the ability to recognise the participation of these objects in the manufacturing of realities. Just as in the example from anthropology (that culture is dependent on the ethnographic account), so also in our case: the vulnerability of same-sex attracted women in Brazil is dependent on, is mediated through, the work carried out by the articles we studied.

We find that the ethnographic approach we have used has multiplied the ways in which the health of same-sex attracted women in the Brazilian published literature can be grasped. Because once vulnerability came into being through the work of publishing, we could again ask what are the surroundings in which such a claim can be made. In this last and final draft, we applied the concept of intertextuality to the lesbian body, in order to take into account the associations participating once the lesbian body could be claimed as vulnerable. From intertextuality, we employ the general notion of 'several texts within the text' ${ }^{64}$ in which the lesbian body can be explained as an 'intersection of textual surfaces ${ }^{65}$ and an intersection of other texts. The following quotation is again taken from Almeida's abstract:

The epidemic contributed to this continuing invisibility, due to strong beliefs in which the "lesbian body" would be the only one immune 
to the infection through the sexual via. The hypothesis guiding this paper is based on the idea that lesbians vulnerability is the "passport" for affirmation/inclusion of a certain identity mark in public policies agenda. ${ }^{66}$

The notion of intertextuality makes it possible to conclude that within the studied articles we could identify other texts, which we had no direct access to. Alongside the associations we had already described-the A and B claim making structure, and the invisible and female features-we could now recognise a political text as co-participant in the manufacturing of a vulnerable 'lesbian body'. The notion of intertextuality conceives of the creation of a text as a reading and absorption of the anterior literary corpus, as a dialogue with other texts. ${ }^{67}$ Texts are more than written entities. They embody everything else that was surrounding the creation of the text, as for instance thought, history and political circumstances. ${ }^{68}$ Because interviews take place at a certain place and time in history, they inevitably respond to and dialogue with the environment in which they happened. Blood tests are required in a certain setting, and produced in relation to this setting. In the case of this review, the setting was a political one.

While identifying that political texts participate in scientific projects may not represent a fresh insight, intertextuality has provided us with a way to trace the political action of scientific publications. By applying both the notion of inscription and the concept of intertextuality to the 'lesbian body', we could make a final claim: in the papers we studied, vulnerabilities and the findings endorsing them are the outcome of a process that involves the transformation of events into scientific publications with political implications.

This is not to say that the scientific is coming about only to fulfil sheer political aims. In our review, it means to recognise that a lot more than interviews, tests and scientific publication take part in establishing that same-sex attracted women are vulnerable. The notion of intertextuality blurred the separation between science and politics. The political does not precede the scientific. Political subjectivities are necessary parts in the objective scientific endeavour. Intertextuality enabled a transformation of the line dividing these two arenas into a juncture. A scientific vulnerability became political. The practice of publishing evidence is a political practice.

\section{Final considerations}

At the end, let us briefly reflect on the pathways we have chosen to follow in this review, and where these ways have gotten us.

This paper differs from and challenges conventional methods for reviewing scientific and scholarly literature. We did not provide a summary of the main findings about female homosexuality and health in Brazil. We did not argue that same-sex attracted women are at risk for this or that disease.

Yet, this challenge is not an opposition in itself. We have decided to operate in a system of thought in which making such claims would have no meaning. We chose to refrain from assuming that because publications state risks of diseases, one can infer that same-sex attracted women in Brazil are exposed to these risks. However, we proceed this way not to attack such deductions as bad research practice. Rather, by refraining from accepting an interchangeable link between papers and realities outside them, we highlighted that these deductions are assumptions. We wished only to remind the reader and ourselves that the processes and changes happening between bench and bedside, between testing blood and writing papers, between interviewing women and creating textual entities, are often forgotten.
In this paper, we did not come to conclusions about the health of same-sex attracted women living in Brazil. In our way of thinking, we could only make conclusions about publications, about texts that came to be produced after meeting and interviewing women. This does not mean that we have nothing to say about the worlds outside the papers we analysed. The claims we made-that health vulnerabilities are both scientific and political-highlight nuances often dismissed in medical and scientific practices. If the political, as we observed, participates as a co-creator of scientific knowledge, to take on science as a neutral endeavour may have unintended consequences.

Contributors KM suggested the design. CBRS selected the articles and wrote the various versions of the drafts. CBRS translated quotations. KM and HWK provided anthropological foundation. EE provided philosophical background. The four authors discussed all versions of the paper. KM, HWK and EE made critical and detailed comments. All authors have approved the final manuscript.

Funding This study was funded by Universitetet i Oslo.

Competing interests None declared.

Patient consent for publication Not required.

Provenance and peer review Not commissioned; externally peer reviewed.

Open access This is an open access article distributed in accordance with the Creative Commons Attribution Non Commercial (CC BY-NC 4.0) license, which permits others to distribute, remix, adapt, build upon this work non-commercially, and license their derivative works on different terms, provided the original work is properly cited, appropriate credit is given, any changes made indicated, and the use is non-commercial. See: http://creativecommons.org/licenses/by-nc/4.0/.

\section{ORCID iD}

Carolina Rau Steuernagel http://orcid.org/0000-0001-5277-3994

\section{NOTES}

1. Susan Gal (2015), "Politics of Translation," Annual Review of Anthropology no. 44, 226.

2. Jacques Derrida (1982), Positions, trans. Alan Bass, 2nd ed. (Chicago: University of (hicago Press), 20.

3. Bruno Latour and Steve Woolgar (1986), Laboratory Life: The Construction of Scientific Facts, 2nd ed. (Princeton: Princeton University Press).

4. Ibid; Jacques Derrida (2016), Of Gramatology, trans. Gayatri Chakravorty Spivak, 4th ed. (Baltimore: Johns Hopkins University Press).

5. Julia Kristeva (1986), "Word, Dialogue and Novel," in The Kristeva Reader, ed. Toril Moi (New York: Columbia University Press).

6. Ibid., 37.

7. Nicholas J Fox (1995), "Intertextuality and the Writing of Social Research," Electronic Journal of Sociology 1, no. 2.

8. Trisha Greenhalgh (1998), "Narrative Based Medicine in an Evidence Based World," in Narrative Based Medicine: Dialogue and Discourse in Clinical Practice, ed. Trisha Greenhalgh and Brian Hurwitz (London: BMJ Books); Helen Lambert (2006), "Accounting for EBM: Notions of Evidence in Medicine" Social Science and Medicine 62, no. 2006; Vincanne Adams (2016), Metrics: What Counts in Global Health (London: Duke University Press); Christopher J Colvin (2015), "Anthropologies in and of Evidence Making in Global Health Research and Policy," Medical Anthroplogy 34, no. 2.

9. Morten Wang Fagerland (2015), "Evidence-Based Medicine and Systematic Reviews," in Research in Medical and Biological Sciences: From Planning and Preparation to Grant Application and Publication, ed. Petter Laake, Haakon Breien Benestad, and Bjorn Reino Olsen (London: Elsevier), 432.

10. Trisha Greenhalgh, Jeremy Howick, and Neal Maskrey (2014), "Evidence Based Medicine: A Movement in Crisis?," BMJ 348, no. 3725; Maya J Goldenberg (2006), "On Evidence and Evidence-Based Medicine: Lessons from the Philosophy of Science," Social Science and Medicine 62, no. 2006.

11. Greenhalgh, Howick, and Maskrey, "Evidence Based Medicine: A Movement in Crisis?"

12. Eivind Engebretsen, Tony Joakim Sandset, and John Ødemark (2017), "Expanding the Knowledge Translation Metaphor," Health Research Policy and Systems 15, no. 19, 3.

13. Julia Kristeva et al. (2018), "Cultural Crossings of Care: An Appeal to the Medical Humanities," Medical Humanities 44, no. 1: 55.

14. Marilyn Strathern (2004), Partial Connections, Updated ed. (Walnut Creek: Altamira Press), 7.

15. Although we borrow the example of anthropology, we highlight that similar reflections on representation have happened across many different fields. 
16. James Clifford and George E. Marcus (1986), Writing Culture: The Poetics and Politics of Ethnography (Berkeley and Los Angeles: University of California Press); John Van Maanen (2011), Tales of the Field: On Writing Ethnography, 2nd ed. (Chicago: The University of Chicago Press).

17. Strathern, Partial Connections, 7.

18. Clifford and Marcus, Writing Culture: The Poetics and Politics of Ethnography, 2.

19. Latour and Woolgar, Laboratory Life: The Construction of Scientific Facts.

20. Strathern, Partial Connections, 9.

21. James Leach (2010), "Intervening with the Social? Ethnographic Practice and Tarde's Image of Relations Between Subjects," in The Social after Gabriel Tarde: Debates and Assessments, ed. Matei Candeia (London and New York: Routledge), 204.

22. Strathern, Partial Connections, 9.

23. Fagerland, "Evidence-Based Medicine and Systematic Reviews."

24. Annemarie Mol (2002), The Body Multiple: Ontology in Medical Practice, (Durham and London: Duke University Press), 155.

25. Strathern, Partial Connections.

26. Kåre Moen and Anne-Lise Middelthon (2015), "Qualitative Research Methods," in Research in Medical and Biological Sciences: From Planning and Preparation to Grant Application and Publication, ed. Petter Laake, Haakon Breien Benestad, and Bjorn Reino Olsen (London: Elsevier).

27. Bruno Latour (2005), Reassembling the Social: An Introduction to Actor-Network Theory, (Oxford: Oxford University Press).

28. Ibid.

29. Ibid., 46

30. Ibid., 47

31. Helena Lucia B Dos Reis et al. (2010), "Genital and Oral Human Papillomavirus Infection in a Patient from the Group of Women Who Have Sex with Women," Clinics 65, no. 12.

32. Sarah Crowe et al. (2011), "The Case Study Approach." BMC Med Res Methodol 11.

33. Reis et al., "Genital and Oral Human Papillomavirus Infection in a Patient from the Group of Women Who Have Sex with Women," 1383.

34. Ibid.

35. Ibid., 1385.

36. Ibid., 1383, 84 .

37. Ibid., 1383

38. Daniela Comelis Bertolin et al. (2010), "Knowledge of Women Who Have Sex with Women About Human Papillomavirus," Cogitare Enfermagem 15, no. 4.

39. Mol, The Body Multiple, 160.

40. Latour and Woolgar, Laboratory Life.

41. Regina Maria Barbosa and Mitti Ayako Hara Koyama (2006), "Women Who Have Sex with Women: Estimates for Brazil," Cad Saude Publica 22, no. 7, 1511.

42. Valdir Monteiro Pinto et al., 2005, "Sexually Transmitted Disease/HIV Risk Behaviour among Women Who Have Sex with Women," AIDS 19 Suppl 4, 64.

43. Ibid., 65

44. Ibid. 67, 68.

45. Ibid.

46. Reis et al., "Genital and Oral Human Papillomavirus Infection in a Patient from the Group of Women Who Have Sex with Women," 1383.

47. Pinto et al., "Sexually Transmitted Disease/Hiv Risk Behaviour among Women Who Have Sex with Women," 64.

48. Regina Maria Barbosa and Regina Facchini (2009), "Access to Sexual Healthcare for Women Who Have Sex with Women in Sao Paulo, Brazil," Cadernosde Saúde Publica 25 no. $2,292$.

49. Claudia Mora and Simone Monteiro (2010), "Vulnerability to STIs/HIV: Sociability and the Life Trajectories of Young Women Who Have Sex with Women in Rio De Janeiro," Culture, Health and Sexuality 12, no. 1,115.

50. Barbosa and Facchini, "Access to Sexual Healthcare for Women Who Have Sex with Women in Sao Paulo, Brazil," 291.

51. Ibid., 294.

52. Ibid.

53. Guilherme Silva de Almeida (2009), "Arguments of the Possibility of STD Infection and Aids among Women that Define Themselves as Lesbians," Physis:Revista de Saúde Coletiva 9, no. 1.

54. Ibid., 303.

55. Derrida, Of Gramatology

56. Julia Kristeva (2002), " "Nous Deux" or a (Hi)Story of Intertextuality." The Romanic Review 93, no. 1-2.

57. Latour and Woolgar, Laboratory Life; Derrida, Of Gramatology.

58. Derrida, Positions, 26.
59. Ibid

60. Almeida, "Arguments of the Possibility of STD Infection and Aids among Women that Define Themselves as Lesbians," 305.

61. Ibid.

62. Ibid., 302.

63. Derrida, Of Gramatology.

64. Kristeva, "Word, Dialogue and Novel," 37.

65. Ibid., 36

66. Almeida, "Arguments of the Possibility of STD Infection," 331.

67. Kristeva, "Word, Dialogue and Novel," 39.

68. Kristeva, "Nous Deux" or a (Hi)Story of Intertextuality."

69. Pinto et al, "Sexually Transmitted Disease/HIV Risk Behaviour among Women Who Have Sex with Women."

70. Barbosa and Koyama, "Women Who Have Sex with Women: Estimates for Brazil."

71. Gláucia Almeida and Maria Luiza Heilborn (2008), "Não Somos Mulheres Gays: Identidade Lésbica Na Visão De Ativistas Brasileiras," Gênero 9, no. 1.

72. Regina Facchini (2008), "Mulheres, (Homo)Sexualidades e Diferenças: Uma Reflexão Sobre Políticas Públicas Segmentadas," in 26Reunião Brasileira de Antropologia (Porto Seguro (BA)).

73. Almeida, "Arguments of the Possibility of STD Infection."

74. Barbosa and Facchini, "Access to Sexual Health Care."

75. Reis et al., "Papillomavirus."

76. Mora and Monteiro, "Vulnerability to STIs/HIV: Sociability and the Life Trajectories of Young Women Who Have Sex with Women in Rio De Janeiro."

77. Julliana Luiz Rodrigues and Néia Schor (2010), "Saúde Sexual e Reprodutiva de Mulheres Lesbicas e Bissexuais," Fazendo Gênero 9: Diásporas, Diversidades, Deslocamentos (Florianópolis (SC)).

78. Bertolin et al., "Knowledge of Women Who Have Sex with Women About Human Papillomavirus."

79. Rita de Cássia Valadão and Romeu Gomes (2011), "Female Homosexuality in Health: From Invisibility to Violence," Physis: Revista de Saúde Coletiva 21, no. 4.

80. Claudia Mercedes Mora and Simone Monteiro (2013), "Female Homoeroticism, Young People and Vulnerability to STI/AIDS," Estudos Feministas 21, no. 3.

81. Patrícia Maria Gomes de Carvalho et al. (2013), "Prevention of Sexually Transmitted Diseases by Homosexual and Bisexual Women," Online Brazilian Journal of Nursin 12, no. 4.

82. Cintia Souza Carvalho, Fernanda Calderaro, and Solange Jobin e Souza (2013), "The Device "Health of Lesbian Women." : (in)Visibility and Rights," Psicologia Política 13, no. 26.

\section{BIBLIOGRAPHY}

Adams, Vincanne. Metrics: What Counts in Global Health. London: Duke University Press, 2016

Almeida, Gláucia, and Maria Luiza Heilborn. "Não Somos Mulheres Gays: Identidade Lésbica Na Visão de Ativistas Brasileiras." Gênero 9, no. 1 (2008): 225-49.

Almeida, Guilherme Silva de. "Arguments of the Possibility of STD Infection and Aids Among Women That Define Themselves as Lesbians." Physis: Revista de Saúde Coletiva 9, no. 1 (2009): 225-49.

Barbosa, Regina Maria, and Mitti Ayako Hara Koyama. "[Women Who Have Sex with Women: Estimates For Brazil]." Cadernos de saude publica 22, no. 7 (2006): 1511-4.

Barbosa, Regina Maria, and Regina Facchini. "Access to Sexual Health Care for Women Who Have Sex with Women in Sao Paulo, Brazil." Cadernos de Saúde Publica 25, no. 2 (2009): 291-300.

Bertolin, Daniela Comelis, Rita de Cássia H. M. Ribeiro, Claudia Bernardi Cesarino, and Dayana Coelho da Silva. "Knowledge of Women who Have Sex with Women About Human Papillomavirus." Cogitare Enfermagem 15, no. 4 (2010): 730-5.

Carvalho, Cintia Souza, Fernanda Calderaro, and Solange Jobin e Souza. "The Device "Health of Lesbian Women": (in)Visibility and Rights." Psicologia Política 13, no. 26 (2013): 111-27.

Carvalho, Patrícia Maria Gomes de, Bibiana Sidartha Martins Nóbrega, Jayce Lima Rodrigues, Rejane Oliveira Almeida, Fernanda Tavares de Mello Abdalla, and Lucia Yasuko Izumi Nichiata. "Prevention of sexually transmitted diseases by homosexual and bisexual women: a descriptive study." Online Brazilian journal of nursing 12, no. 4 (2013): 931-41.

Clifford, James, and George E. Marcus. Writing Culture: The Poetics and Politics of Ethnography. Berkeley and Los Angeles: University of California Press, 1986.

Colvin, Christopher J. "Anthropologies in and of Evidence Making in Global Health Research and Policy." Medical Anthropology 34, no. 2 (2015): 99-105.

Crowe, Sarah, Kathrin Cresswell, Ann Robertson, Guro Huby, Anthony Avery, and Aziz Sheikh. "The Case Study Approach." BMC Medical Research Methodology 11, no. 1 (2011): 100 . 
Derrida, Jacques. Positions. Translated by Alan Bass, 2nd edn. Chicago: University of Chicago Press, 1982.

. Of Gramatology. Translated by Gayatri Chakravorty Spivak, 4th edn. Baltimore: Johns Hopkins University Press, 2016.

Engebretsen, Eivind, Tony Joakim Sandset, and John Ødemark. "Expanding the Knowledge Translation Metaphor." Health Research Policy and Systems 15, no. 19 (2017): 4.

Facchini, Regina. "Mulheres, (Homo)Sexualidades E Diferenças: Uma Reflexão Sobre Políticas Públicas Segmentadas." 26 Reunião Brasileira de Antropologia, vol. 22. Porto Seguro, 2008.

Fagerland, Morten Wang. "Evidence-Based Medicine and Systematic Reviews." In Research in Medical and Biological Sciences: From Planning and Preparation to Grant Application and Publication, edited by Petter, Laake, H. B, Benestad, and B. R, Olsen. London: Elsevier, 2015.

Fox, Nicholas J. "Intertextuality and the Writing of Social Research." Electronic Journal of Sociology 1, no. 2 (1995): 1-11.

Gal, Susan. "Politics of Translation." Annual Review of Anthropology 44, no. 1 (2015): 225-40.

Goldenberg, Maya J. "On Evidence and Evidence-Based Medicine: Lessons from the Philosophy of Science." Social Science and Medicine 62, no. 2006 (2006): 2621-32.

Greenhalgh, Trisha. "Narrative Based Medicine in an Evidence Based World." In Narrative Based Medicine: Dialogue and Discourse in Clinical Practice, edited by T, Greenhalgh, and B, Hurwitz. London: BMJ Books, 1998.

Greenhalgh, Trisha, Jeremey, Howick, Neal Maskrey. "Evidence Based Medicine: A Movement in Crisis?" BMJ 348, no. 3725 (2014), 7.

Kristeva, Julia In. The Kristeva Reader, edited by T, Moi. New York: Columbia University Press, 1986.

. " "Nous Deux" or a (Hi)Story of Intertextuality." The Romanic Review 93, no. 1-2 (2002): 7-13.

Kristeva, Julia, Marie Rose Moro, John Ødemark, and Eivind Engebretsen. "Cultural Crossings of Care: an Appeal to the Medical Humanities." Medical Humanities 44, no. 1 (2018): 55-8.

Lambert, Helen. "Accounting for EBM: Notions of Evidence in Medicine." Social Science \& Medicine 62, no. 2006 (2006): 2633-45.
Latour, Bruno, and Steve Woolgar. Laboratory Life: The Construction of Scientific Facts, 2nd edn. Princeton: Princeton University Press, 1986.

Latour, Bruno. Reassembling the Social: An Introduction to Actor-Network Theory. Oxford University Press: Oxford, 2005.

Leach, James. "Intervening with the Social? Ethnographic Practice and Tarde's Image of Relations between Subjects." In The Social after Gabriel Tarde: Debates and Assessments, edited by M, Candeia. New York: Routledge, 2010.

Maanen, John Van. Tales of the Field: On Writing Ethnography, 2nd edn. Chicago: The University of Chicago Press, 2011.

Moen, Kåre, and Anne-Lise Middelthon. "Qualitative Research Methods." In Research in Medical and Biological Sciences: From Planning and Preparation to Grant Application and Publication, edited by P, Laake, H. B, Benestad, and B. R, Olsen. London: Elsevier, 2015.

Mol, Annemarie. The Body Multiple: Ontology in Medical Practice. Durham and London: Duke University Press, 2002.

Mora, Claudia, and Simone Monteiro. "Vulnerability to STIs/HIV: Sociability and the Life Trajectories of Young Women Who Have Sex with Women in Rio de Janeiro." Culture, Health \& Sexuality 12, no. 1 (2010): 115-24. and Simone Monteiro. "Female Homoeroticism, Young People and Vulnerability to STI/AIDS." Estudos Feministas 21, no. 3 (2013): 905-26.

Pinto, Valdir Monteiro, Mariza Vono Tancredi, Antonio Tancredi Neto, and Cássia Maria Buchalla. "Sexually Transmitted Disease/HIV Risk Behaviour among Women Who Have Sex with Women." AIDS 19, no. Suppl 4 (2005): S64-9.

Reis, Helena Lucia B Dos, Dennis Carvalho Ferreira, Aline Garcia Forattini, Philippe Godefroy Souza, Jose Alexandre da Rocha Curvelo, and Mauro Romero Leal Passos. "Genital and Oral Human Papillomavirus Infection in a Patient from the Group of Women Who Have Sex with Women." "Clinics 65, no. 12 (2010): 1383-5.

Rodrigues, Julliana Luiz, and Néia Schor. "Saúde Sexual E Reprodutiva De Mulheres Lesbicas E Bissexuais." Fazendo Gênero 9: Diásporas, Diversidades, Deslocamentos. Florianópolis, 2010

Strathern, Marilyn. Partial Connections. Walnut Creek: Altamira Press, 2004.

Valadão, Rita de Cássia, and Romeu Gomes. "Female Homosexuality in Health: From Invisibility to Violence." Physis: Revista de Saúde Coletiva 21, no. 4 (2011): 1451-67. 